\title{
Praktik Prosumption Kalangan Kelas Menengah Yogyakarta di Instagram: Culture, Network Society
}

\author{
Rama Kertamukti ${ }^{*}$ \\ ${ }^{1}$ Prodi Ilmu Komunikasi UIN Sunan Kalijaga Yogyakarta \\ Jl. Laksda Adi Sutjipto, Yogyakarta 55281 - Indonesia \\ "Email korespondensi: kawanrama@gmail.com
}

\begin{abstract}
Abstrak
Prosumption melibatkan praktik produksi dan konsumsi tidak berfokus pada salah satu praktik produksi atau praktik konsumsi saja dalam Instagram, dan ini seringkali dilakukan oleh kelas menengah. Ada realitas yang dimediasi tidak hanya terdiri dari konteks komunikasi massa namun merupakan proses total dari mediasi kehidupan. Instagram dalam konteks kultural juga dipahami oleh kelas menengah dengan melakukan kontruksi, negosiasi dan rekontruksi makna produksi dan konsumsi. Penelitian ini menggunakan etnografi virtual dengan akun yang diteliti @ herni_maryulianidan @ rosakusumaazhar, keduanya adalah bagian dari kelas menegah dan aktif dalam menggunakan instagram dalam kehidupannya. Hasil yang diperlihatkan dalam melakukan produksi dan konsumsi diwakili kedua subyek ini sebagai kelas menengah adalah pengguna instagram yang beraktivitas dengan yang mengunggah foto ataupun mengomentari foto, mereka juga mengunggah barang di situs online dalam kata lain kelas menengah berupaya menjadi pengguna yang mengkonsumsi materi yang ada di instagram tetapi juga sangat aktif dalam memproduksi pesan untuk dikonsumsi pengguna lain dengan makna leisure economy.
\end{abstract}

Kata Kunci: Kelas Menengah, Produksi, Konsumsi, Instagram, Budaya

\section{PENDAHULUAN}

Instagram sebagai komoditi dunia siber juga ingin menyatukan dan menjadi bagian dari gaya hidup masyarakat, keterhubungan antar pengguna Instagram dapat terjadi setiap saat selama terhubung-online, karena hampir disetiap aktivitas pengguna dapat diabadikan dan dipublikasikan ke dalam instagram dalam hitungan detik. Keefektifan, efisiensi, cepat, interaktif dan variatif menjadi andalan Instagram. Media sosial ini mengejar para pesaingnya seperti Facebook, maupun Twitter. Instagram memacu aplikasinya dalam menghadirkan photo sharing (berbagi foto) di aktivitasnya. Media sosial berbasis pada berbagi foto mulai menjadi primadona seiring makin mudahnya orang menangkap momen-momen dengan berbagai perangkat fotografinya. Selain mudah dan simple, dengan berbagi gambar atau foto sebenarnya kita tidak hanya menunjukkan apa yang sedang kita lihat, kerjakan atau rasakan namun lebih dari itu kita bisa menyampaikan pesan di dalamnya. Hal ini menjadi salah satu nilai tambah kenapa Instagram makin diminati. Layanan berbagi foto tidak hanya sebagai kebutuhan personal, kini juga mulai dilirik tangan-tangan kreatif dalam dunia industri. Para enterprenuer dan korporat sudah bisa menangkap celah positif photo sharing sebagai media promosi dan perluasan bisnisnya bahkan personal brand mereka. Berbeda dengan Facebook dan Twitter, Instagram menggunakan foto sebagai media penyampai pesan dimana ia dibaca sebagai sebuah teks. Foto dilekati tanda yang dapat berfungsi sebagai petanda dan penanda sekaligus yang terjadi ketika sebuah narasi didalam foto dari si penulis dimaknai oleh si pembaca narasi dalam ruang yang dihadirkan melebur dalam ruang offline-online.

Instagram diciptakan oleh Kevin Systrom dan Mike Krieger, dan didirikan pada bulan Oktober 2010. Instagram adalah sebuah aplikasi berbagi foto yang memungkinkan pengguna mengambil foto, menerapkan filter digital, dan membagikannya ke berbagai layanan jejaring sosial, termasuk milik Instagram sendiri. Satu fitur yang unik di Instagram adalah memotong foto menjadi bentuk persegi, sehingga terlihat seperti hasil kamera Kodak Instamatic dan polaroid. Hal ini berbeda dengan rasio aspek 4:3 yang umum digunakan oleh kamera pada peranti bergerak. Instagram dapat digunakan di iPhone, iPad atau iPod Touch versi apapun dengan sistem operasi iOS 3.1.2 atau yang terbaru, dan telepon genggam Android apapun dengan sistem operasi versi 2.2 (Froyo) ke atas. 
p-ISSN: 0853-4470 - Vol. 02, No. 01 (2019), pp. 34-47 Aplikasi ini dapat diunggah melalui Apple App Store dan Google Play. Instagram berasal dari pengertian dari keseluruhan fungsi aplikasi ini. Kata "insta" berasal dari kata "instan", seperti kamera polaroid yang pada masanya lebih dikenal dengan sebutan "foto instan". Instagram juga dapat menampilkan foto-foto secara instan, seperti polaroid di dalam tampilannya. Sedangkan untuk kata "gram" berasal dari kata "telegram" yang cara kerjanya untuk mengirimkan informasi kepada orang lain dengan cepat. Sama halnya dengan Instagram yang dapat mengunggah foto dengan menggunakan jaringan Internet, sehingga informasi yang ingin disampaikan dapat diterima dengan cepat. Oleh karena itu, Instagram merupakan gabungan dari kata instan dan telegram.

Popularitas Instagram digunakan di Indonesia dapat dilihat dari data yang dihadirkan Jakpat (open survei platform dengan jumlah responden terdaftar sebanyak 18.000 orang, mengusung survei bersifat real-time di mana pengguna bisa langsung mendapat data survei yang dapat dipantau secara langsung). Di Indonesia, tahun 2016 telah memasang dan menggunakan Instagram pada smartphone mereka sejak 1 hingga 2 tahun yang lalu. Hal ini cukup masuk akal mengingat tahun-tahun tersebut merupakan peralihan pengguna ponsel di tanah air dari Blackberry ke smartphone Android dan iOS. Sekitar 53 persen responden mengungkapkan bahwa aktivitas sehari-hari merupakan hal yang paling sering mereka bagikan di Instagram. Sedangkan foto selfie berada di urutan selanjutnya, yakni sekitar 33 persen responden lebih sering membagikan foto selfie mereka. Tingkah laku menarik berikutnya adalah 75 persen responden menyatakan bahwa mereka menggunakan Instagram untuk mencari dan mengikuti akun vendor seperti fashion dan toko online.

Indonesia adalah negara pengguna Instagram kedua terbesar di Asia (nomor 4 di dunia). Jumlah pengguna aktif per bulan di Indonesia meningkat menjadi $2 x$ lebih banyak tahun ke tahun (Januari 2016), 57\% pengguna Instagram di Indonesia telah menggunakannya 1-2 tahun terakhir. Pengguna Instagram di Indonesia tergolong aktif. 97\% dari mereka sering berkomentar dan mention teman-teman mereka di bagian komentar, $21 \%$ pengguna Instagram di Indonesia mengunggah 1-2 foto setiap hari, 71\% pengguna Instagram di Indonesia mengecek akunnya setiap mereka ada waktu luang, $12 \%$ melakukan ini sedikitnya 1 kali setiap jam. $89 \%$ pengguna Instagram di Indonesia berumur 18 - 34 tahun, 63\% pengguna Instagram di Indonesia adalah perempuan Hanya $7 \%$ pengguna Instagram di Indonesia mem-posting foto makanan atau minuman, $45 \%$ pengguna Instagram di Indonesia sering membeli barang-barang yang mereka temukan di Instagram (akun vendor) (https://blog.jakpat.net/category/mobile/ diakses pada 28 September 2017).

Sadar ataupun tidak, realitas virtual yang dihadirkan dalam dunia siber ini semakin mudah dan murah dalam memberikan kontribusi yang signifikan bagi realitas virtual. Seolah-olah dapat dikatakan entitas menjadi terikat dengan dunia virtual dan dunia offline-online tidak hanya terhubung secara parallel, tetapi melebur dan menyatu (Boellstorff, Nardi, Pearce, \& Taylor, 2012:1). Instagram menjadi ruang pamer foto, menjadi semacam ruang pribadi karena galeri pengguna bisa di desain sedemikian rupa sesuai kehendak pengguna, pengguna mengunggah apa saja yang terjadi di sekitar mereka, yang dianggap mewakili aktivitas pengguna. Kadangkala motif untuk mengunggah teks berupa caption, foto atau gambar, suara tidak secara jelas ditujukan kepada siapa. Komunikasi menjadi tidak bisa dijelaskan kepada siapa yang terlibat di dalamnya atau kepada siapa teks berupa caption, foto atau gambar, dan suara itu ditujukan. Uniknya dalam dunia siber pengguna seperti di Instagram secara bersamaan bisa menjadi produsen sekaligus sebagai konsumen dari status mereka atau disebut (Prosumer). Istilah Prosumer dikaitkan dengan Alvin Toffler dalam bukunya The Third Wave (Toffler, 1980:266), pada bab The Rise of the Prosumer, bahwa pada Gelombang Pertama, manusia hanya mengkonsumsi apa yang mereka dapat produksi, lalu bergeser pada Gelombang Kedua yang mana masyarakat terbagi atas dua fungsi, produsen dan konsumen. Sehingga dapat dipahami bahwa pada Gelombang Kedua terdapat pergeseran makna produksi, dari production for use ke production for exchange.

Dalam Gelombang Ketiga yang terjadi adalah kelanjutan dari proses production for exchange tadi, yaitu munculnya praktek gaya hidup baru. Dalam Instagram, praktik ini dijumpai, kita bisa melihat pengguna yang mengunggah barang jualannya dalam galery mereka, tetapi sekaligus mengkonsumsi komentar-komentar yang follower-nya. Pengguna dapat memilih sendiri informasi apa yang ingin diperolehnya, dan bahkan juga dapat memproduksi informasi sendiri. Wertime dan 
Fenwick (Kent Wertime, 2008:222), menyebutnya sebagai consumer-created content, di mana pengguna media kini disebut dengan prosumer, karena mereka juga menjadi produsen informasi. Sehingga pengguna media kini bukan lagi target pasif, namun menjadi partisipan aktif juga. Fenomena konten diproduksi dan dikonsumsi oleh pengguna Instagram seperti ini bisa dianggap sebagai mass self communication (Castells, 2010: xxvii). Sistem komunikasi berjejaring dan digital yang terbentuk dalam ruang yang disebut internet ini menyebabkan entitas (pengguna maupun perangkat) memunculkan model komunikasi tersendiri yang berbeda.

Komunikasi di dunia siber tidak lagi mensyaratkan adanya komunikator-komunikan dan relasi. Pesan seolah-olah diproduksi dan disimpan dalam gudang pustaka penyimpanan data secara online yang siapa saja, termasuk pengguna yang memproduksi pesan, bisa mengonsumsi pesan yang diinginkan olehnya. Dalam Instagram fenomena tersebut hadir, follower dan pemilik akun saling memproduksi dan mengkonsumsi. Berbagai dimensi kehidupan mengalami redefinisi dan diferensiasi terjadi secara meluas menunjukkan sifat relatif praktik sosial begitupula dalam kalangan kelas menengah yang mempunyai porsi banyak dalam menghabiskan waktunya untuk Instagram. Cara-cara kelas menengah mempraktikkan budayanya juga mengalami perubahan, bukan karena aktivitas kelas menengah yang mengalami proses kontekstualisasi sehingga budaya embedded di dalam masyarakat, tetapi juga karena budaya yang mengkontekstualisasi budaya itu merupakan tata nilai yang berbeda di dalam kelas menengah.

Kelas menengah menurut Ariel Heryanto, merupakan kategorisasi sosial yang dipahami secara bervariasi, bahkan acapkali saling berlawanan. Heryanto menegaskan, beberapa pandangan yang saling berlawanan terlanjur dominan dalam kajian kelas menengah Indonesia. Ada yang berpendapat bahwa kelas menengah dalam masyarakat ini (seharusnya) secara moral hebat dan progresif (Heryanto, 2004:51). Menurut Heryanto, yang lazim sama dalam semua ragam kelas menengah (tanpa kesamaan ini mereka tidak dapat disebut sebagai kelas menengah) adalah kiblat atau ikatan mereka pada gabungan beberapa hal berikut ini: tinggal di perkotaan; pekerjaan dan pendidikan modern; dan selera budaya, yang tampil secara mencolok, tetapi tidak semata-mata, dalam konsumsi gaya hidup. Hal lain yang mempersamakan kedua kutub tersebut adalah bahwa secara ekonomi, orang-orang dalam kelas menengah menduduki posisi yang jelas berbeda, dari mereka yang lazim disebut kelas pekerja. Mereka juga berbeda dari kelompok yang paling diuntungkan dalam tatanan sosial yang ada berkat kekuasaan ekonomi atau birokratis mereka yang besar (Heryanto, 2004:54). Penyokong utama gaya hidup adalah kelas menengah karena begitu intensifnya kelas ini berkonsumsi. Baudrillard melihat pola konsumsi masyarakat modern ditandai dengan bergesernya orientasi konsumsi yang semula ditujukan bagi "kebutuhan hidup", menjadi "gaya hidup". Baginya, hal tersebut tak lepas dari munculnya kelas menengah pasca-Perang Dunia II secara masif akibat diterapkannya konsep ekonomi keynesian. Bagi Baudrillard, hal terkait menunjukkan betapa dewasa ini masyarakat lebih terpaku pada konsumsi simbol ketimbang kegunaan. Konsumsi memegang peranan penting dalam hidup manusia. Konsumsi membuat manusia tidak mencari kebahagiaan, tidak berusaha mendapatkan persamaan, dan tidak adanya intensitas untuk melakukan homogenisasi, manusia justru melakukan diferensiasi (perbedaan) yang menjadi acuan dalam gaya hidup dan nilai, bukan kebutuhan ekonomi (Guide, Bergson, Haraway, Husserl, \& Lechte, 2008: 354).

Penelitian ini memfokuskan pada praktik produksi dan konsumsi dalam bingkai budaya siber dan network society. Kajian mengenai budaya siber telah banyak dilakukan, penelitian bersumber pada digital, percepatan waktu interaktivitas, tetapi budaya siber hipertekstual, dispersal, virtualitas, dengan non-linearity, dan pemamfaatan jarak, modularity, re-mediasi, demasiffikasi, asynchronicity, dan konvergensi (Des Freedman dalam Curran, James, 2012: 69-117) belum banyak didalami lebih jauh. Seperti, budaya siber Digital yang dimaksudkan bagaimana bentuk data digital ini dapat menjadi lebih baik penggunaannya dari data analog dalam segi kecepatan dan ke-real-annya yang berbasis digital dan hanya dapat dilakukan dengan media komputer. Meski saat ini media siber juga sudah dapat diakses dengan teknologi mobile seperti smartphone sebagai pengembangan media komputer. Penelitian dalam bingkai budaya siber digital dalam smartphone dapat ditelusuri dalam penelitian Mite Setiansah (2015), yang mengungkap Kehadiran smartphone dalam kehidupan sehari-hari bertransformasi dalam dunia digital menghadirkan perempuan urban dalam kultur baru yang berbeda 
dengan kultur bermedia sebelumnya.

Karakteristik interaktivitas kemudian menjadi karakterisik favorit diteliti oleh beberapa peneliti. Interaktif dalam dunia siber dapat memotong waktu, secara langsung dapat dikendalikan dan komunikasinya bersifat dua arah dapat terjadi hanya dengan media komputer saja. Pengaturan informasi yang kreatif dari karakter inilah yang juga menjadi pilihan pengguna dalam teknologi media ini. Meski sebenarnya interaksi tersebut terjadi antara manusia dan komputer. Beberapa catatan yang menarik mengenai ini adalah penelitian berjudul "Dukungan Sosial dan Interaktivitas terhadap Keputusan Konsumen melakukan Pembelian melalui Sosial Commerce" (2015) oleh Dewi Puspawati, dalam penelitiannya mengungkap peningkatan popularitas interaksi sosial dalam situs jejaring sosial, seperti Facebook, Twitter, dan Instagram telah membuka kesempatan untuk membuka model bisnis baru dalam perdagangan elektronik, yang biasa disebut dengan social commerce. Pengguna yang ingin membeli melalui s-commerce dapat saling mempengaruhi pengguna lain dengan word of mouth, rekomendasi, dan perpindahan pengetahuan (transfer knowledge) pada jejaring sosial.

Penelitian ini mengeksplorasi fenomena praktik budaya masyarakat jaringan (network society) di kalangan kelas menengah dalam memperlihatkan perubahan signifikan yang lebih fleksibel, tidak ada batasan ruang dan waktu dalam consumer-created content di ruang instagram, bahkan didalamnya masyarakat jaringan dapat saling menjadi konsumen sekaligus produsen dalam berbagai praktik. Sehingga pengguna media kini bukan lagi target pasif, namun menjadi partisipan aktif.

\section{KERANGKA TEORI}

Internet menurut Hine (2007) bisa didekati dalam dua aspek apabila menggunakan pendekatan etnografi, yakni internet sebagai budaya dan internet sebagai artefak kebudayaan. Perbedaan ini berimplikasi - khususnya untuk para peneliti etnografi - kepada perbedaan penggunaan metodologi dalam penelitian di satu sisi maupun secara tegas memaparkan keuntungan maupun kelemahan di sisi lain.

Sebagai sebuah budaya (culture), pada awalnya internet dianggap sebagai model komunikasi yang sederhana bila dibandingkan dengan model komunikasi secara langsung atau face-toface (Baym, 1998). Bahwa interaksi face-to-facetidak hanya melibatkan teks sebagai simbol atau tanda dalam berinteraksi semata. Ekspresi wajah, tekanan suara, cara memandang, posisi tubuh, agama, usia, ras, dan sebagainya merupakan tanda-tanda yang juga berperan dalam interaksi antarindividu. Sedangkan dalam interaksi dalam computer mediated communication terjadi berdasarkan teks semata bahkan emosipun ditunjukkan dengan menggunakan teks, yakni dengan simbol-simbol dalam emoticon.

Sebenarnya media baru dalam dunia siber menawarkan adanya ruang privat dan ruang publik. Namun semuanya diputuskan oleh individu sendiri sebagai pengguna apakah ingin menggunakan media ini untuk keprivatan identitasnya ataukah ia ingin membagi dengan pengguna lain. Dalam ruang publik yang "padat" bentuk komunikasi berlangsung secara argumentatif dan dialogis. Hal ini masih dalam bentuk komunikasi yang rasional. Dalam ruang siber disediakan ketersediaan ruang publik yang dapat dikatakan bebas. Setiap individu merasa tidak diawasi atau diintervensi oleh siapapun termasuk pemerintah. Karena itulah individu dapat dengan mudah mengubah identitas atau membuat informasi tentang dirinya sesuai dengan keinginannya tanpa merasa bersalah atau disalahkan. Hampir tidak mungkin tiap pengguna mendapatkan intervensi dan pengaturan secara khusus dari pihak lain (Green, 2010: 48).

Pengguna dalam dunia siber secara bebas dapat membuat informasi yang benar-benar baru mengenai dirinya di dunia ini. Dengan demikian satu individu sudah dapat membuat identitas baru tentang dirinya kepada dunia baru juga. Identitas tersebut tentunya sulit untuk dibuktikan kenyataannya (Green, 2010: 130). Bisa saja semua informasi yang pengguna masukkan dalam akunnya adalah fiktif atau fakta, tidak ada yang tahu kecuali jika kita memang mengenalnya dekat didunia nyata. Hal-hal itu yang menimbulkan kompleksitas hubungan sosial dalam komunikasi siber dan dangkalnya sifat konten informasi yang turun pada budaya dalam produksi informasi di media sosial. Budaya siber seringkali mempunyai intepretasinya sendiri dalam menghasilkan pemaknaan kompleks dalam informasi, ketika hubungan yang sebenarnya dangkal dalam ruang siber, yang hanya 
didapatkan dan terbentuk dari pertukaran informasi seadanya dalam ruang siber ini di interpretasikan lebih oleh individu-individunya, sebuah teks yang di unggah dalam ruang siber dapat di interpretasikan berbeda oleh pengguna lain, padahal si pembuat tidak bermaksud membuat interpretasi tersebut. Dalam ruang siber, dapat terjadi permainan identitas didalamnya. Dimungkinkan tiap pengguna dapat memiliki identitas baru, identitas palsu, identitas ganda yang semuanya merupakan bagian dari identitas budaya ruang siber. Bahkan individu yang dinamakan pengguna ruang siber yang memiliki identitas ganda dapat dikatakan telah membelah dirinya, membelah pribadinya.

Dalam dunia siber, dapat terjadi permainan identitas didalamnya. Tiap pribadi dimungkinkan untuk memiliki identitas baru, identitas palsu, identitas ganda yang semuanya merupakan bagian dari identitas budaya cyberspace. Bahkan individu yang memiliki identitas ganda dapat dikatakan telah membelah dirinya, membelah pribadinya. Identitas dalam dunia siber digunakan hanya ketika pengguna sedang dalam keadaan online dalam ruang cyber. Dalam dunia yang lain masih dimungkinkan ia memiliki identitas yang berbeda. Tidak adanya konsistensi ini salah satu bentuk hilangnya identitas diri manusia. Selain itu, dalam tingkat individu, dunia siber dapat menimbulkan sifat ketergantungan bahkan dalam tingkat antar individu. Ruang sosial dunia nyata dapat kita cari bentuknya dalam dunia baru ini. Hubungan sosial dunia nyata juga dapat terjadi disini. Teman, sahabat, pacar ataupun musuh dapat terjadi dalam dunia siber. Dengan demikian hal ini mengindikasikan adanya deteritorialisasi sosial, ketika hubungan-hubungan sosial tidak lagi membutuhkan ruang dan bentuk yang nyata (konvensional). Konsekuensinya yakni istilah "mendekatkan yang jauh dan menjauhkan yang dekat" (Bell, 2001:2).

\section{Praktik Instagram dalam Dunia Siber}

Menjadi anggota jaringan sosial media tertentu biasanya berbanding lurus dengan latar belakang sosial. Itulah yang diperoleh dari sebuah penelitian Pew Research Center yang dipublikasikan oleh Slate.fr. Menurut penelitian pendapatan orang mempengaruhi arah seorang remaja menjadi bagian dari sosmed mana. Dalam kesimpulannya, remaja dari kalangan orang berpenghasilan sangat baik akan memilih berbagi foto di Instagram, sedangan mereka yang yang orang tuanya dari kelas rata-rata akan berbagi pesan di Facebook. Meski demikian, Facebook dikenal sangat disukai oleh remaja (71\%) dibandingkan dengan Instragram (52\%), Snapchat (41\%), dan Twitter (33\%). Instagram adalah aplikasi media sosial yang diakses oleh semua kalangan, terutama yang memiliki perangkat memadai, karena operasional Instagram membutuhkan spesufikasi yang harus memadai karena berbasis pada foto (pixel tinggi).

Melalui Instagram, seseorang dapat mengunggah foto atau video, mempublikasikannya, dan terpampang pada galery pengguna yang lain. Seiring berjalannya waktu, penggunaan media sosial Instagram tidak sekedar media untuk komunikasi namun beralih menjadi media ajang pamer, khususnya di kalangan kelas menengah. Pengguna instagram dapat memiliki perangkat yang mendukung aplikasi Instagram, yaitu android phones maupun iPhone. Karena spesifikasi yang dibutuhkan itu, Instagram memiliki pengguna yang rata-rata kelas menengah. Instagram menjadi ruang kelas menengah untuk memajangkan kehidupan pribadi serta pencitraan diri mereka melalui foto yang diunggah. Ruang pribadi anak muda mulai beralih menjadi ruang publik. Pamer yang dilakukan berupa penampilan fashion, traveling, gaya hidup, dan sebagainya. Keinginan kelas menengah untuk diakui menuntut mereka menampilkan dirinya sebagai pribadi yang sesuai mereka inginkan. Instagram adalah barang konsumsi, konsumsi memegang peranan penting dalam hidup manusia. Seperti yang dikemukakan lehte, konsumsi membuat manusia tidak mencari kebahagiaan, tidak berusaha mendapatkan persamaan, dan tidak adanya intensitas untuk melakukan homogenisasi, manusia justru melakukan diferensiasi (perbedaan) yang menjadi acuan dalam gaya hidup dan nilai, bukan kebutuhan ekonomi (Guide et al., 2008).

Instagram adalah salah satu aplikasi media sosial yang diakses oleh semua kalangan, terutama kalangan anak muda. Melalui Instagram, seseorang dapat mengunggah foto atau video, mempublikasikannya, dan terpampang pada feed pengguna yang lain. Sistem pertemanan yang ada di Instagram menggunakan istilah follower (pengikut) dan following (orang yang diikuti). Terdapat 
fitur like dan comment sehingga orang dapat leluasa memberikan apresiasi berupa tanda suka atau komentar pada foto yang diunggah. Manfaat dari penggunaan Instagram adalah sebagai media promosi, informasi, dan menyalurkan ide kreatif melalui foto. Seiring berjalannya waktu, penggunaan media sosial Instagram tidak sekedar media untuk komunikasi namun beralih menjadi media ajang pamer dan berjualan. Instagram menjadi wadah bagi para pengguna untuk memperlihatkan kehidupan pribadi serta presentasi diri mereka melalui foto yang diunggah. Ruang pribadi mulai beralih menjadi ruang publik. Presentasi di ruang-wall pengguna Instagram yang dilakukan banyak berupa penampilan fashion, traveling, gaya hidup, dan sebagainya.

\section{Prosumption}

Gaya hidup konsumsi masyarakat Gelombang Ketiga ini adalah gaya-gaya hidup yang setengah didasarkan pada produksi bagi jual-beli, dan setengahnya produksi untuk pemakaian sendiri. Kebangkitan prosumen pasti akan mengubah jalan pemikiran, yang mana akan menggeser dasar dari sengketa ekonomi. Kompetisi yang terjadi antara pekerjaan-produsen dan manajer-produsen masih akan terus berlanjut. Namun, dengan bergeraknya masyarakat sekarang yang lebih pada masyarakat Gelombang Ketiga maka masalah yang akan muncul lebih ke konflik sosial yang baru. Dengan begitu kebangkitan prosumen ini telah mengubah panorama ekonomi dunia. Apalagi dengan adanya internet yang semakin membuat manusia mendapat segala kemudahan. Seperti contohnya, ketika kita ingin memasak makanan dari luar negeri, misalnya saja Korea Selatan, kita tidak perlu lagi harus menyewa koki ternama yang berasal dari negara Korea Selatan, ataupun harus datang ke Korea Selatan. Kita cukup menekan satu tombol kemudia akan muncul berbagai resep makanan khas Korea Selatan, dan tentu saja kita dapat membuatnya sendiri. Dengan begitu, kita dapat membuat sesuatu untuk diri kita sendiri tanpa harus mengeluarkan biaya berlebih karena harus menyewa tenaga ahli ataupun harus berkunjung ketempat asal produk tersebut. Selain itu juga kita dapat menjual hasil produksi kita sendiri tersebut ke orang lain. Dengan begitu kebangkitan prosumen ini berkaitan erat dengan berkembangnya teknologi informasi di dunia ini. Hal ini juga menegaskan bahwa teknologi informasi mempunyai pengaruh dalam merubah pola konsumsi masyarakat dunia saat ini.

Prosumption merupakan suatu proses yang melibatkan produksi dan konsumsi. Prosumption seringkali ditunjukkan saat konsumen terlibat dalam memproduksi sebagian atau keseluruhan suatu hal yang dikonsumsi dirinya atau konsumen lain (Ritzer \& Jurgenson, 2010: 14). Dalam perkembangannya presumption tidak harus terjadi dalam suatu waktu (Ritzer, 2014: 160-161). Fasilitas dan kemampuan teknologi yang dihadirkan internet memungkinkan peleburan produsen dan konsumen, menjadikan semua pengguna internet seorang prosumer (Haraway dalam Ritzer, 2014). Maraknya blog adalah maraknya kecenderungan "prosumsi". Istilah prosumsi diperkenalkan Alvin Tofler melalui "Future Shock" yang terbit pada 1970-an (Toffler, 1971:3). Kemajuan teknologi, seperti internet, memungkinkan setiap orang menjadi produsen dan konsumen informasi sekaligus. Secara keseluruhan, ini adalah kejatuhan hirarki terpusat dan memandang ke depan untuk masyarakat yang lebih tersebar dan responsif, dihuni oleh hibrida dari konsumen dan produsen yang ia sebut "prosumer".

Dalam dunia siber prosumption menjadi praktik yang dijumpai dalam ruang-ruangnya. Kita bisa melihat pengguna yang mengunggah foto dan juga mengomentari foto, mengunggah barang di situs online sekaligus mengkonsumsi di jual beli online. Dalam ruang siber tidak ada aktivitas dari pengguna seperti instagram sebagai media sosial yang murni merupakan praktik konsumsi atau murni mempraktikkan produksi saja. Pengguna yang mengkonsumsi foto diruang Instagram akan juga menjadi produsen ketika dia mengunggah fotonya di ruang feed-gallery mereka. Jumlah love yang bertambah banyak memperlihatkan fotonya disukai.

Prosumption semakin dimungkinkan dalam era siber. Pengguna atau orang yang hadir dalam dunia siber bisa menjadi seorang prosumer tanpa disadari. Ada beberapa ciri dari prosumer di era siber ini, seperti yang dikutip dalam Ritzer (Ritzer, 2014). Pertama adalah prosumer melakukan aktivitas yang jarang. Bahkan, seseorang itu tidak pernah dilakukan sebelumnya. Seperti berbagi foto dan lagu kepada orang lain, yang jarang dilakukan secara offline. Kedua, prosumer melakukan aktivitas tersebut seringkali tanpa menerima bayaran. Pengguna Instagram contohnya, ia 
mengunggah foto untuk menjual barang tanpa menerima kompensasi apapun oleh pihak pengembang Instagram. Ketiga, perusahaan atau pengembang seperti Instagram tempat aktivitas presumption menerima keuntungan dari aktivitas tersebut. Instagram akan menerima banyak konten iklan yang melalui aplikasinya karena penggunanya semakin banyak yang saling berinteraksi. Keempat, pengguna banyak memperoleh fasilitas secara gratis. Instagram tidak perlu membayar untuk apapun yang dihadirkan di feed atau galeri para pengguna Instagram bahkan Instagram memberikan banyak keleluasaan dan mempercantik foto-foto yang akan ditampilkan di Instagram bahkan memberikan fasilitas filter photo. Kelima, semua aktivitas presumption ini ditunjang oleh kemajuan teknologi, pengaksesan semakin mudah bahkan menggunakan teknologi upload-download-sharing konten yang semakin mudah. Prosumer bisa mempratikkan prosumption yang berbeda sesuai keinginan mereka dalam ruang siber. Prosumer bisa condong melakukan presumption as production dalam ruang tertentu atau melakukan presumption as consumption di saat yang lain.

\section{METODE PENELITIAN}

Penelitian di ruang siber memerlukan metode yang khusus. Hal ini dikarenakan banyaknya kekhasan dalam ruang siber yang membedakannya dengan praktik di ruang offline. Teknologi ruang siber mempunyai konsekuensi tersendiri, dalam ruang siber memungkinkan seseorang untuk mempraktikan budaya lama dengan cara-cara baru. Ruang siber sebagai sebuah bagian dari konteks budaya juga memungkinkan untuk dikaji dengan menggunakan etnografi. Peneliti akan memakai metode etnografi untuk mencari dan menganalisis data praktik budaya presumption di Instagram pada kalangan kelas menengah di Yogyakarta. Dengan etnografi maka peneliti bisa melihat suatu wacana dari sudut pandang subjek yang diteliti (Saukko, 2003: 57). Etnografi juga akan berusaha melihat secara lebih luas mengenai realitas subjek yang dikaji. Etnografi bisa memberikan cara pandang baru mengenai pelabelan praktik budaya sesuatu, misalnya mengenai konsep resistensi (Saukko, 2003: 56). Subjek penelitian ini adalah dua akun @ herni_maryuliani dan @ rosakusumaazhar sebagai kelas menengah. Keduanya kelas menengah yang menghabiskan pengeluaran pribadinya rata-rata 2 juta keatas.

Dalam konteks dunia siber yang diteliti ruang-ruang di dalamnya, peneliti akan memakai metode etnografi virtual. Pendekatan etnografi virtual akan dilakukan karena penelitian ini obyeknya dalam ruang siber, sehingga cukup dapat memahami cara subjek berinteraksi dan bekerjasama melalui fenomena yang teramati dalam kehidupan sehari-hari baik dalam keseharian maupun dalam penggunaan instagram. Penelitian etnografi di internet yang menjadi persoalan adalah interaksi peneliti dengan subjek (Hine, 2000:43-57). Dalam etnografi keberadaan peneliti, subjek penelitian, dan lokasi penelitian itu hadir dalam bentuknya yang nyata. Ada tempat yang bisa dikunjungi secara nyata sesuai dengan lapoan hasil penelitian. Juga, berdasarkan hasil penelitian tersebut kita juga bisa bertemu dengan orang-orang yang menjadi subjek atau informan yang memberikan pernyataan atau yang diamati. Sebab, melakukan penelitian etnografi di lapangan maka etnografer berada dalam posisi simetris dengan subjek yang diteliti. Pengertian simetris di sini adalah antara peneliti dan subjek berada dalam pola komunikasi yang sama, memiliki pemahaman yang sama, keduanya saling bertatap muka dan mengenal-memperkenalkan diri, dan data yang dihasilkan juga berdasarkan konteks yang dipahami antara keduanya.

\section{HASIL PENELITIAN}

Instagram adalah dunia dimana para penggunanya dikondisikan menampilkan dirinya lewat kehadiran dirinya dalam bingkai-bingkai foto atau gambar, secara teknis Instagram adalah media sosial berbagi foto. Berbagi foto membuat pengguna bebas mengkontruksi dirinya sesuai keinginan. Praktik yang dilakukan instagram untuk penggunannya dibahasakan oleh Pilliang sebagai diri ketika di dalam dunia siber setiap "ada" (beings) dirubah wujudnya menjadi "ada citra" (being images). Setiap ontologi dirubah menjadi "ontologi citraan", tiap realitas dibuatkan subtitusi-subtitusinya berupa "citra realitas" (Piliang, 2012), dan itu dilakukan oleh informan dua akun @ herni_maryuliani dan @rosakusumaazhar sebagai kelas menengah. 
Instagram sebagai bagian dari dunia siber melepaskan obsesi para penggunanya untuk mengolah citra mereka sesuai yang mereka inginkan dalam sebuah foto. Foto yang dihadirkan Dedi memperlihatkan Informan dapat mengembangkan berbagai bentuk aktivitas kehidupan seperti nyata yang mempunyai sifat artificial, aplikasi edit mendukung proses itu semua sehingga foto yang diunggah sesuai dengan keinginan. Begitu menikmatinya dua akun @herni_maryuliani dan @ rosakusumaazhar sebagai kelas menengah terlihat dengan sering mengunggah foto maupun video di Instagram stories dengan aktivitasnya. Di dalam instagram, mereka bisa mengolah dan mengedit gambar yang diinginkan, berubah wujud, hidup dalam berbagai ruang yang tidak sama dalam kesempatan waktu yang sama dalam ruang wujud citraan di dalam galeri Instagram. Fenomena yang terjadi dunia nyata berubah menjadi sekumpulan citra-citra apa adanya, dan citra apa adanya menjadi sebuah kenyataan, When the real world is transformed into mere images, mere images become real beings (Debord, 1967).

Informan merasakan apa yang tidak dapat dilakukan di dalam dunia yang padat-offline, dapat dilakukan dalam di instagram. Penjara tubuh yang melekat dalam keseharian di ruang nyata dapat terlepas di ruang-ruang instagram. Instagram memberikan peluang untuk informan terlepaskan diri dari beban kerja, tekanan jiwa, tekanan politik, tekanan keluarga, tekanan masyarakat industri yang benar-benar menekan, seperti yang dikemukakan Margaret Wertheim bahwa cyberberspace menjelma menjadi sebuah tempat penjelajahan psikososial, penjelajahan untuk menemukan "self", peran, identitas dan eksistensi (Wertheim, 2000: 233). Fenomena itu dihadirkan oleh informan Rosa, ia bisa menyembunyikan sakit yang diderita dalam dunia nyata. Tetapi berbeda ketika di Instagram, ia bisa menampilkan kebahagian berkopi ria di Instagram. ampilan foto dan video memberikan persepsi bahwa ia penyuka kopi.

Kerelaan Informan meninggalkan media sosial lainnya seperti Facebook dan Twitter menjadi simbol bahwa media sosial yang lagi disukai di kalangan kelas menengah adalah Instagram (wearesosial.com, 2018). Instagram dirasakan bisa menawarkan kebebasan bagi informan untuk menavigasikan diri mereka sendiri. Instagram memberi fasilitas Informan sebagai pengguna Instagram untuk membawa kemana arah presentasi diri mereka di dalam ruang Instagram hingga dikonsumsi oleh "teman-teman". Instagram menjadikan diri menjadi "seseorang", terlihat dalam deskripsi yang diunggah, foto dan bentuk layout yang diatur sedemikian rupa oleh informan. Dunia yang menurut Heidegger "his world" (Heidegger, 1977: xxvii), tampilan bercitra indah dihadirkan di galeri Instagram seakan kenyataan tetapi sejatinya sarat rekayasa. Dalam dunia simulasi berlaku hukum simulacra, yaitu "daur ulang atau reproduksi objek dan peristiwa". Seperti yang dilakukan Rosa ketika diklarifikasi mengenai foto-foto yang ditampilkan di Instagram, apakah foto itu memang seperti yang ditampilkan. Di WA messenger dia menjawab bahwa semua fotonya harus diseting sesuai dengan tema yang diinginkan untuk ditampilkan. Rosa menginginkan Instagramnya menampilkan ia yang enerjik.

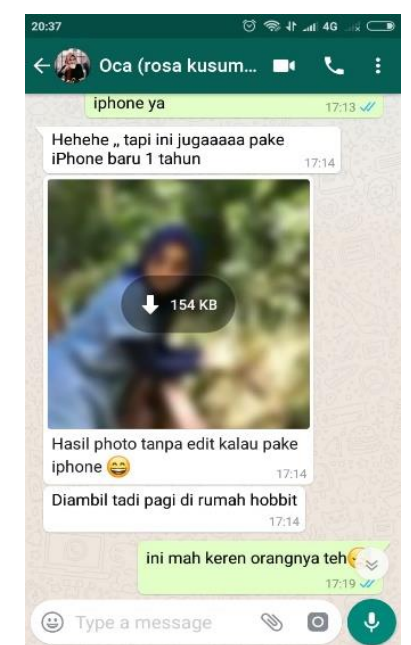

Gambar 1. Klarifikasi Rosa atas Foto di Instagramnya di WA Messenger 
p-ISSN: 0853-4470 - Vol. 02, No. 01 (2019), pp. 34-47

Instagram menjadi dunia yang dikendalikan oleh citra yang tidak lagi menyisakan pencarian diri otentik (authentic self), citra-citra dalam instagram diproduksi informan untuk mendapatkan perhatian dengan segala fasilitas yang disediakan. Informan Mahfud mengungkapkan bahwa menggunakan instagram untuk memperlihatkan aktivitasnya sangat menyenangkan karena respon dari teman-teman cepat dan banyak yang nge-like. Instagram membuat informan untuk memilih foto yang benar-benar diolah terlebih dahulu sebelum diunggah. Informan menyadari bahwa ia dapat memproduksi konten yang dapat ia unggah kapanpun tanpa batas. Internet telah menjadikan konsumen memiliki kemampuan dan dampak yang lebih kuat dalam memproduksi dan mendistribusikan informasi dibanding dengan apa yang disediakan oleh produsen (Xiang \& Gretzel, 2010). Teknologi instagram telah memfasilitasi penggunanya sedemikian rupa untuk selalu peka terhadap dirinya untuk selalu diperbaiki, diedit untuk memuaskan dirinya sendiri dan dia berharap bagi yang mengkonsumsi foto dan videonya yang diunggah.

Mengkonsumsi, berkontribusi, dan menciptakan adalah perilaku yang senantiasa rutin ketika memasuki ruang media sosial, "sosial media provide unlimited means for internet users to interact, express, share and create content about anything”(Muntinga, Moorman, \& Smit, 2011: 15). Mengkonsumsi adalah tindakan yang termudah dalam beraktivitas bermedia sosial, hanya membuka halaman-halaman pengguna lain tanpa berkontribusi membuat konten seperti membaca dan menonton. Sedangkan aktivitas menengah adalah share, membagikan konten yang merupakan interaksi antara pengguna dengan konten serta di antara pengguna lain, termasuk berpartisipasi dalam forum atau mengomentari postingan pengguna lain di ruang comment. Sedangkan membuat konten adalah aktivitas paling tinggi dalam bermedia sosial, kegiatan ini melibatkan produksi dan mengunggah konten dan ini berhubungan disukai atau tidak oleh pengguna lain. Kegiatan ini menghabiskan waktu cukup banyak bagi penggunanya.

Membuat konten dalam Instagram membutuhkan jumlah upaya mencari pengetahuan yang berbeda dari yang lain. Orang-orang menggunakan lebih banyak upaya kognitif ketika membuat tulisan atau mengunggah foto daripada ketika mengkonsumsi pesan (Piolat, Olive, \& Kellogg, 2005). Itu dirasakan betul oleh Herni @herni_maryuliani, ia membuat konten harus benar-benar sesuai dengan lingkungannya sebagai istri seorang pengusaha yang memiliki kolega di mana-mana dan sebagai istri yang memiliki 2 orang anak perempuan. Informan benar-benar menjaga apa yang diunggahnya di instagram, Suami-Anak-Kolega-Teman baru dan hubungan ini saling mengkait. Pernah dalam kesempatan salah seorang teman anaknya yang masih kelas 3 SMP, mengungkapkan ke Informan, "Tante cantik sekali, seneng ngeliat Instagram tante".

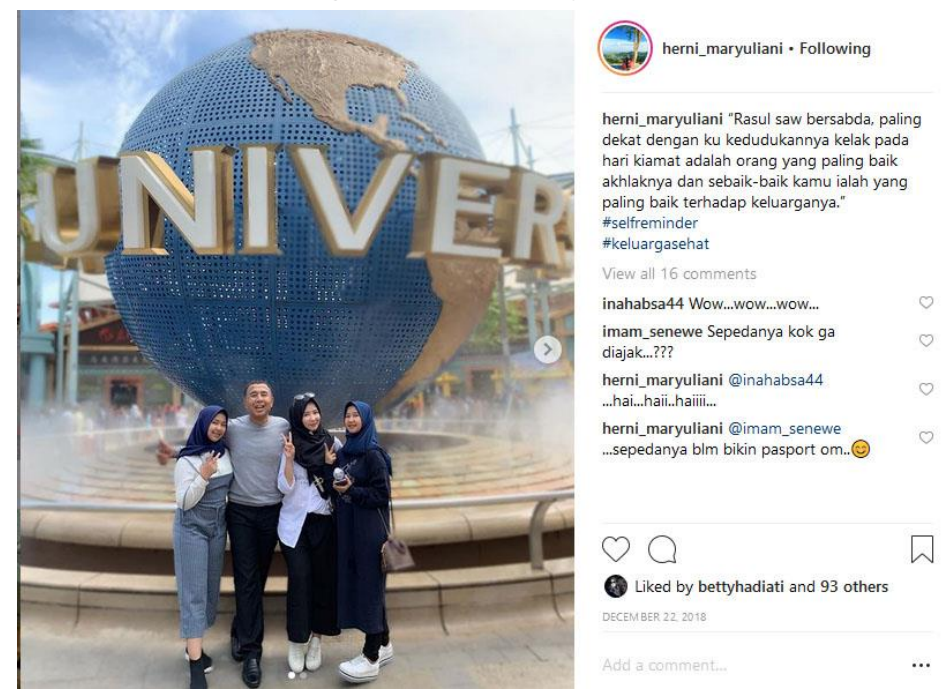

Gambar 2. Informan Herni dan keluarga di Instagram

Instagram menjadi kehidupan kedua, sehingga apa yang terjadi di dunia offline tersambung di dunia online. Sesuatu yang dibagikan (share) individu di online menjadi sesuatu yang ada korelasinya dengan dunia offline. Perangkat digital menjadi penunjang kegiatan dan bahkan kebutuhan sehari- 
p-ISSN: 0853-4470 - Vol. 02, No. 01 (2019), pp. 34-47

hari individu untuk beraktivitas. Digital life ini sangat menarik bagi Informan, pertanyaan sederhana bagi Herni apakah ia banyak menghabiskan waktu untuk menjelajahi dunia Instagram, ia menjawabnya bahwa ia tidak begitu banyak menghabiskan waktu, "Pas nunggu di mobil, pas santai dirumah saja kok..." Tetapi ketika ditanya agak mendalam, apakah dilakukan tiap hari, Informan mengiyakan. Kenikmatan berselancar di dunia Internet memang tidak terasa, terangkum dalam laporan Hootsuite.com bahwa di Indonesia media sosial dikonsumsi rata-rata 3 jam 23 menit. Konsumsi Instagram bagi Herni menjadi conspicuous leisure yang menempel dalam kegiatannya, "The act of consuming" adalah tindakan dalam memanfaatkan, menggunakan, atau menikmati sesuatu yang bersifat material atau nonmaterial.

Herni hanya sesekali menghapus unggahan di galeri Instagram miliknya, baginya aktivitas membagi pengalaman yang terjadi dalam keseharian bisa menyambung relasi dan memberikan pesan kepada follower-nya. Pesan-pesan yang dihasilkan dan diunggah galeri sangat disukai, seperti yang dibuat di 19 Desember 2018 ini,

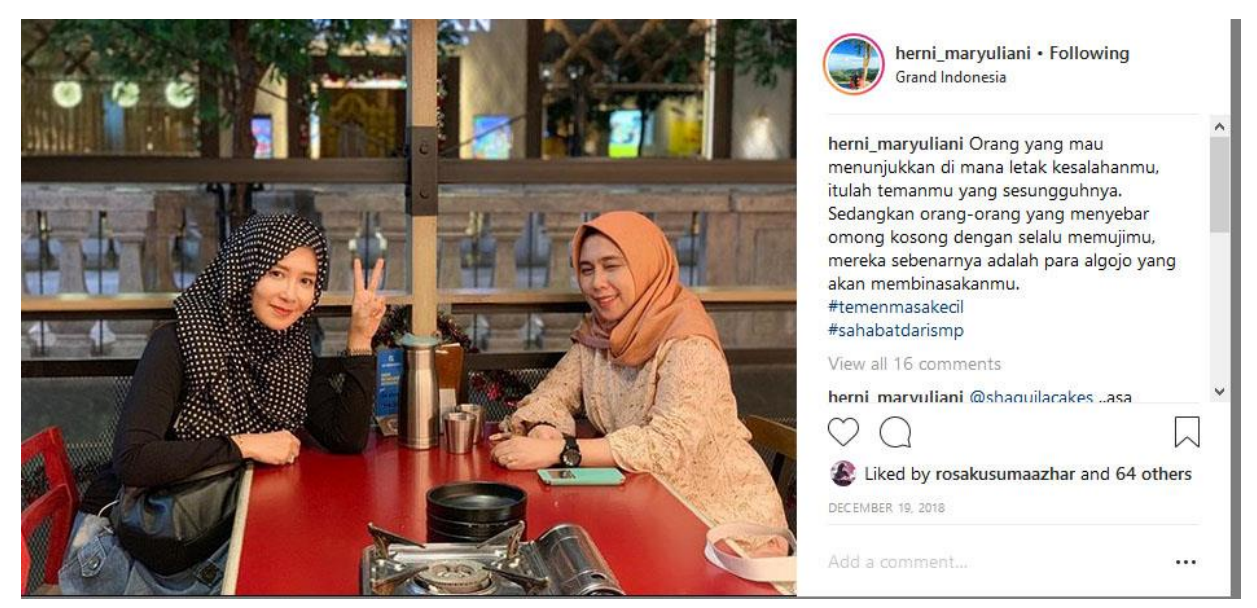

Gambar 3. Informan Herni beserta teman dan captionnya

"Orang yang mau menunjukkan di mana letak kesalahanmu, itulah temanmu yang
sesungguhnya. Sedangkan orang-orang yang menyebar omong kosong dengan selalu
memujimu, mereka sebenarnya adalah para algojo yang akan
membinasakanmu".\#temenmasakecil \#sahabatdarismp (caption Herni 19 Desember 2019)

Caption yang dibuat, dikomentari beragam oleh para teman-teman di Instagram, @ 303asep, "Mantaff djiwaaa(-); @ @nice nila, "Setujuuuuuu teh, ndee masih ngabodor wae nya teh", @ dindaidris, "iishhh seleub @ herni_maryuliani “, @mahshaquilacakes, "ish ish iiiiissshh cateuuut... (0):-)" saling mengkomentari status dalam Instagram adalah kehidupan ber-Instagram. Menariknya ketika Informan saling berkomentar mereka merasa seperti teman dekat, sering bertemu. "teteh mah anggap mereka teman semua, walau suka sadar, suka lupa ini siapa yang mana ya?" ujar Herni menanggapi kenal atau tidak dengan yang mengkomentari dirinya di galerinya. Kedekatan antar pengguna di jejaring sosial pernah diteliti oleh Hiram Tim dkk (2015), mereka menjelaskan bahwa keyakinan perilaku tentang Instagram terdiri dari lima faktor, media sosial mejadi sebuah kepuasan pribadi, fitur kegunaan bagi diri, peran bersosialisasi, mudah mengakses informasi produk dan hiburan, memberikan keyakinan normatif, dan teman-teman di jejaring sosial pun dianggap sebagai saudara kandung, saudara, teman dekat atau teman sebaya, teman pada umumnya, pemberi informasi. (Ting \& Run, 2015)

Dalam berkesempatan mengunggah foto dan caption di instagram milik informan, Informan Herni, Rosa selalu menggunakan waktu yang sama dengan membuka feed pengguna lain dan memberikan like $(\boldsymbol{\vee})$, simbol ini menurut mereka bagian dari silaturahmi digital. Tanda like ( $\boldsymbol{\vee})$ ini mirip dengan yang dipunyai facebook karena Instagram telah diakuisisi Facebook. Tanda bahwa 

pengguna lain menyukai foto yang diunggah adalah memberi tanda like $(\boldsymbol{\vee})$ menjadi merah $(\boldsymbol{\vee})$. Berdasarkan durasi waktu dan jumlah yang memberi tanda like ( $)$, maka sebuah foto dianggap disukai para teman dijejaringnya. Mengunggah foto dan memberikan like, memainkan peran penting dalam membantu pengguna mempertahankan hubungan dengan ikatan yang kuat dan lemah. Penelitian Yuheng Hu memberikan hasil bahwa pengguna dalam kelompok "berbagi informasi" cenderung lebih banyak berbicara, memposting menyebutkan dan membalas ke pengguna lain agar lebih tertanam dalam interaksi sosial di online, walau tidak ada hubungan langsung antara jumlah pengikut dan jenis pengguna yang ditandai dalam hal foto yang dibagikan. ( $\mathrm{Hu}$, Manikonda, \& Kambhampati, 2004)

Demikian pula, ketika orang berkomitmen pada tingkat perilaku media sosial yang lebih tinggi (yaitu menciptakan pesan-menunggah foto di Instagram), mereka mengerahkan lebih banyak upaya kognitif ke dalam perilaku tersebut. Dengan demikian, beragam perilaku media sosial yang dapat dikategorikan sebagai mengkonsumsi, berkontribusi, dan menciptakan dapat memanifestasikan berbagai tingkat upaya psikologis. Bila dibagi dalam tingkat berinteraksi di instagram; Tingkat pertama, suka adalah yang terendah. Suka membutuhkan komitmen yang lebih sedikit daripada yang lainnya. Sementara satu klik sudah cukup untuk suka, komentar dan bagikan butuh tindakan tambahan yang meminta komitmen ekstra atau upaya kognitif. Kedua, berbagi mungkin lebih tinggi daripada komentar. Saat mengomentari kiriman, kiriman tersebut muncul di dalam kolom comment. Menariknya unggahan pengguna di instagram juga dapat menunjukkan bahwa unggahan juga merupakan bagian dari presentasi diri pengguna. Seperti yang diutarakan Rosa, dia betul-betul memilih foto yang diunggah (seperti unggahan ini, Informan suka dengan kata-kata yang dipilih).
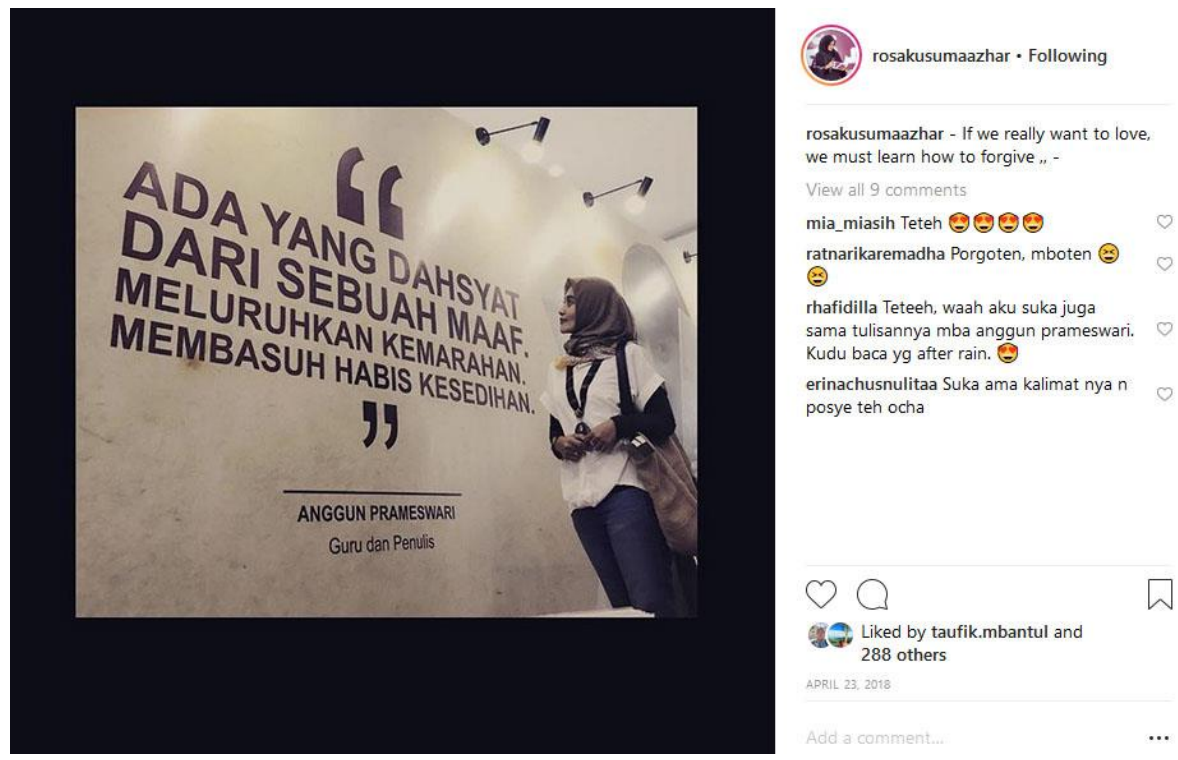

Gambar 4. Unggahan rosa di galeri Instagramnya

Unggahan adalah bagian pengguna media sosial melakukan strategis dalam presentasi diri (van Dijck, 2013) Misalnya, ketika mempresentasikan diri dalam media sosial, individu dengan hatihati mempertimbangkan evaluasi publik (Rui \& Stefanone, 2013) dan apakah presentasi diri online konsisten dengan presentasi diri offline. (DeAndrea \& Walther, 2011) Hal ini menunjukkan bahwa perilaku strategis yang berkaitan dengan presentasi diri dengan unggahan membutuhkan lebih banyak upaya kognitif daripada komentar. Dengan kata lain, saat berbagi kiriman, pengguna lebih berkomitmen untuk memberikan "citra diri" mengenai dirinya daripada saat mengomentari kiriman, cukup menanggapi saja.

Aktivitas mengakses instagram mengkonsumsi, berkontribusi, dan menciptakan konten dalam bentuk like, share, comment adalah aktivitas yang rutin ketika memasuki ruang Instagram, "sosial media provide unlimited means for internet users to interact, express, share and create content about anything”(Muntinga, Moorman, \& Smit, 2011: 15). Mengkonsumsi adalah tindakan yang termudah dalam beraktivitas bermedia sosial, hanya membuka halaman-halaman akun lain 
p-ISSN: 0853-4470 - Vol. 02, No. 01 (2019), pp. 34-47 tanpa berkontribusi membuat konten seperti membaca dan menonton. Sedangkan aktivitas menengah adalah share, membagikan konten yang merupakan interaksi antara pengguna dengan konten serta di antara pengguna lain, termasuk berpartisipasi dalam forum atau mengomentari postingan pengguna lain di ruang comment. Kegiatan itu bisa dilakukan oleh Informan dalam satu paket, seperti Rosa yang sering sekali mengakses Instagram di pagi hari setelah mengurus sarapan dan anak sekolah. Pada jam 08.00-10.00 wib pagi hari adalah waktu Rosa bersenang-senang menjelajah dunia instagram. Sebagai Publik figur, Rosa senantiasa menjaga "silahturahmi digital" dengan teman-teman instagramnya. "Saya kan beda dengan orang kantoran mas, saya kan orang lapangan selalu ketemu orang... jaga pertemanannya bisa lewat instagram", Rosa memberi alasan tentang aktivitasnya di Instagram. Aktivitas like, share dan comment adalah aktivitas sehari-hari yang Rosa lakukan.
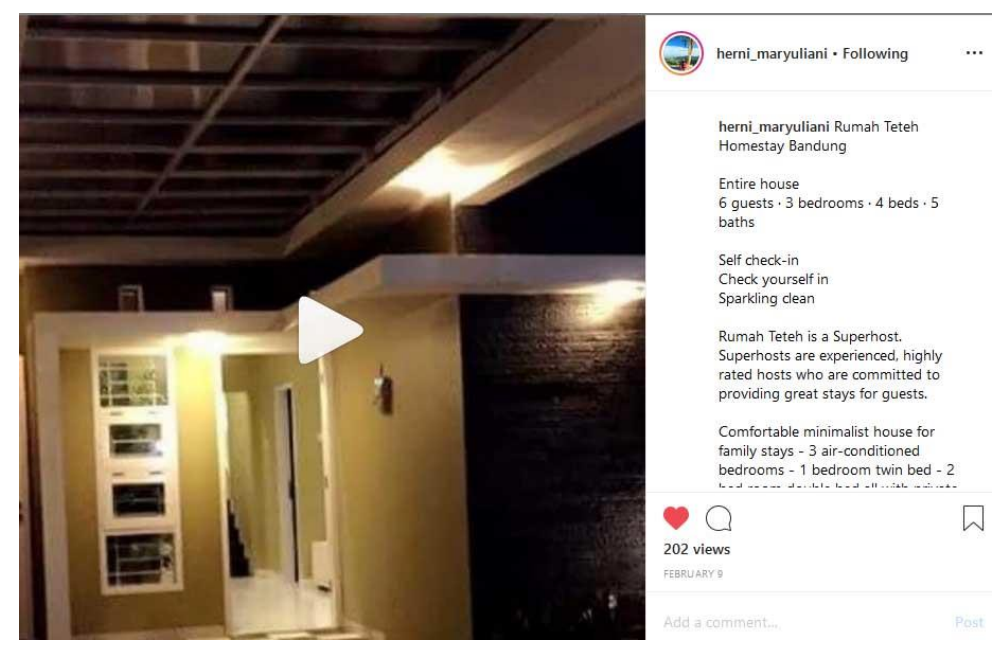

Gambar 5. Aktivitas like, share dan comment Rosa di Instagram

Informan wanita seperti Rosa, Herni, terbiasa untuk melakukan aktivitas like, share dan comment. Rosa bahkan mempunyai jam tetap untuk melakukan aktivitas itu karena ia merasa aktivitas tersebut adalah bagian dari pekerjaannya, ia harus menyapa teman-teman jejaringnya. Herni terbiasa melakukan aktivitas like, share dan comment di jam-jam makan siang. Aktivitas ini dilakukan juga sebagai bagian leisure economy bagi Herni. Ia dapat beraktivitas menikmati hidupnya tetapi juga ia bisa mendapat keuntungan untuk bisnisnya yaitu bisnis properti dengan banyak teman di Instagram. Instagram juga menjadi ruang Herni untuk mempromosikan home stay-nya.

Herni tidak bekerja kantoran walaupun sebelumnya ia adalah seorang bangking di Bukopin tetapi ia memilih bekerja "dirumah", "lebih simple waktunya...", menurut Herni. Mengunggah sesuatu yang bersifat ekonomis juga dilakukan Rosa, ia memperlihatkan pekerjaan apa yang ia lakukan setiap hari sehingga follower-nya mengetahui apa yang dikerjakan Rosa sehari-hari tanpa Rosa harus bercerita macam-macam mengenai aktivitas pekerjaan yang selalu dihadapinya.

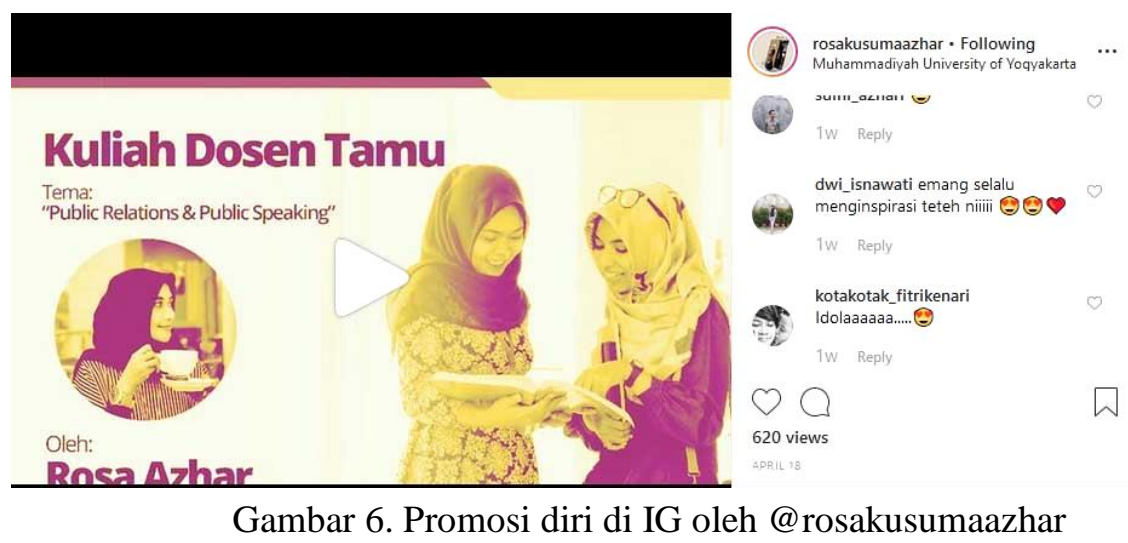

Nana juga memperlakukan kegiatannya dengan aktivitas ekonomi yang isinya bersenang- 
p-ISSN: 0853-4470 - Vol. 02, No. 01 (2019), pp. 34-47 senang sekaligus menghasilkan nilai tambah ekonomi. Dia sangat senang mengakses instagram, ratarata 4 jam ia bisa menghabiskan waktu untuk mengakses Instagram, ia pun melakukan aktivitas like, share dan comment sebagai masyarakat yang prosumtion (memproduksi dan konsumsi juga). Dia bersenang-senang dengan unggahannya tetapi juga ia bisa memberikan nilai ekonomi pada unggahannya di Instagram.

\section{KESIMPULAN}

Prosumption sebagai proses yang melibatkan produksi dan konsumsi-konsumen terlibat dalam memproduksi sebagian atau keseluruhan suatu hal yang dikonsumsinya atau konsumen lain dan ini semua dilakukan Rosa dan Herni sebagai informan. Media sosial memproduksi komoditas yang diunggah para penggunanya untuk dibagi dan dikonsumsi pengguna-pengguna lainnya yang saling berelasi. Dalam dunia siber prosumption menjadi praktik yang dijumpai dalam ruang-ruang informan. Fenomena ini dapat dilihat kedua subyek yang menjadi informan yang mengunggah foto dan juga mengomentari foto, mengunggah barang di situs online sekaligus mengkonsumsi di jual beli online. Dalam ruang siber tidak ada aktivitas dari pengguna seperti instagram sebagai media sosial yang murni merupakan praktik konsumsi atau murni mempraktikkan produksi saja. Pengguna yang mengkonsumsi foto diruang Instagram akan juga menjadi produsen ketika dia mengunggah fotonya di ruang feed-gallery mereka. Jumlah love yang bertambah banyak memperlihatkan fotonya disukai sebagai bagian aku direspon maka aku ada.

\section{Daftar Pustaka}

Bell, D. (2001). An introduction to cybercultures. https://doi.org/10.1108/fs.2002.4.1.44.2

Boellstorff, T., Nardi, B., Pearce, C., \& Taylor, T. L. (2012). Ethnography and virtual worlds: A handbook of method. In Journal of Broadcasting and Electronic Media (Vol. 40). https://doi.org/10.1080/08838159609364336

Castells, M. (2010). The Rise of the Network Society. In Massachusetts: Blackwell Publishing. https://doi.org/10.2307/1252090

DeAndrea, D. C., \& Walther, J. B. (2011). Attributions for inconsistencies between online and offline self-presentations. Communication Research, 38(6), 805-825. https://doi.org/10.1177/0093650210385340

Debord, G. (1967). The Society of the Spectacle by Guy Debord (1967). Society, 6(2), 68-73. https://doi.org/10.1598/JAAL.51.1.7

Green, L. (2010). The Internet. In Berg. https://doi.org/10.1097/00000542-199810000-00024

Guide, K., Bergson, A., Haraway, B., Husserl, H., \& Lechte, J. (2008). F I F T Y K E Y C O N T E M $P$ O R A RY (1nd ed.). New York: Routledge.

Heidegger, M. (1977). The Question Concerning Technology. New York: Garland Publishing, inc.

Hu, Y., Manikonda, L., \& Kambhampati, S. (2004). WhatWe Instagram: A First Analysis of Instagram Photo Content and User Types. ICWSM 2014, 288(4), 431-450. https://doi.org/10.1023/B:ASTR.0000005098.77798.73

Kent Wertime, I. F. (2008). DigiMarketing The Essential Guide to New Media \& Digital Marketing. Singapore: John Wiley \& Sons (Asia) Pte.Ltd.

Muntinga, D. G., Moorman, M., \& Smit, E. G. (2011). Introducing COBRAs Exploring motivations for brand-related social media use. International Journal of Advertising, 30(1), 13-46. https://doi.org/10.2501/ija-30-1-013-046

Piliang, Y. A. (2012). Masyarakat Informasi dan Digital: Teknologi Informasi dan Perubahan Sosial. Jurnal Sosioteknologi, 27(11), 143-156.

Piolat, A., Olive, T., \& Kellogg, R. T. (2005). Cognitive effort during note taking. Applied Cognitive Psychology, 19(3), 291-312. https://doi.org/10.1002/acp.1086

Ritzer, G. (2014). From 'Solid 'Producers and Consumers to 'Liquid 'Prosumers. (January 2014), $157-176$.

Ritzer, G., \& Jurgenson, N. (2010). Production, Consumption, Prosumption. Journal of Consumer Culture, 10(1), 13-36. https://doi.org/10.1177/1469540509354673 
Rui, J. R., \& Stefanone, M. A. (2013). Information , Communication \& Society STRATEGIC IMAGE MANAGEMENT ONLINE. Information, Communication \& Society Vol., 16(8), 12871305. https://doi.org/10.1080/1369118X.2013.763834

Saukko, P. (2003). Doing Research in Cultural Studies. London: SAGE Publications.

Ting, H., \& Run, E. C. De. (2015). Beliefs about the Use of Instagram: An Exploratory Study. International Journal of Business Innovation and Research, (January).

Toffler, A. (1971). Future_Shock (15th ed.). Bantam Books, Inc.

Toffler, A. (1989). The third wave. https://doi.org/10.1017/CBO9781107415324.004

van Dijck, J. (2013). "You have one identity": Performing the self on Facebook and LinkedIn. Media, Culture and Society, 35(2), 199-215. https://doi.org/10.1177/0163443712468605

wearesocial.com. (2018). Digital in Indonesia: A Snapshot of The Countrys Key Digital Statistical Indicators.

Wertheim, M. (2000). The Pearly Gates of Cyberspace. New York: W.W Norton Company.

Xiang, Z., \& Gretzel, U. (2010). Role of social media in online travel information search. Tourism Management, 31(2), 179-188. https://doi.org/10.1016/j.tourman.2009.02.016 